\title{
Experimental Study Concerning Sense of Impropriety for Clothes in Each Aggregation of People by Dolls Model Part 2:In a Group Arrangement of People
}

\author{
Naoko Uchida*, Shigeo Kobayashi* and Yasuhiko Nagakura**
}

\begin{abstract}
In previous section of this report, we discussed about "Sense of Impropriety" of clothes which feels in a "situation" of a random arrangement of people through a sensory evaluation experiment by dolls model. In this report, we aimed to examine the arrangement of groups by the dolls model as well as previous section of this report, and to attempt making the quantification for the sense of impropriety. As to the experiment method, we use the four types for arrangement of aggregation, and the others are similar to previous section of this report. As a result, there is a positive effect when the number wearing the same clothes as the subject increase between a number of dolls as stimulus and the sense of impropriety as well as the random arrangement, and this was found in according with Stevens's Law. And in aggregations of groups of the same number, the sense of impropriety varies with the arrangement of the groups. The sense of impropriety is also influenced by the arrangement. Especially, the sense of impropriety is low when the other clothes aggregation gathers to one side, it is high when the other clothes aggregation divided into both sides. Moreover, the sense of impropriety has changed by the effect of arrangement joining though it is a result in the random arrangement only in clothes effect when seeing from individual clothes, too. Therefore, it was found that the sense of impropriety of "aggregation" was under the influence of not only the quantitative effect and clothes effect but also the effect of arrangement.
\end{abstract}

Key Words : Sense of Impropriety, Sensory Evaluation, Clothes, Dolls Model, Group Arrangement

(Received March 31, 1999)

(Accepted for Publication Aug. 17, 1999)

\section{人形モデルによる集合内の服装の場違い感に関する実験的研究}

\section{（第 2 報）グループ配置の場合}

内田 直子*, 小林 茂雄*, 長倉 康彦**

\section{1. 緒 言}

本研究は, 前報1)に引き続き「集合」の場において 感じる服装の「場違い感」を，心理的な評価実験に より，その数量化を図ることを目的としている．前 報では，人形のモデル実験により，ランダム配置の
「集合」における服装の場違い感を検討した．その結 果, (1)構成要素が 2 つからなる「集合」では，同類

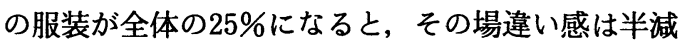
し，75\%を占める段階で場違い感がほぼなくなるこ と, (2)刺激人形数（以下人形数は $\mathrm{S}$ で表す）の一定 領域において, Stevens の法則に従うこと，(3)場違

*Member, Faculty of Home Economics, Kyoritsu Women's University, Hitotsubashi, Chiyoda，会員，共立女子大学家政学部，千 代田区一ツ橋, ${ }^{* *}$ non-Member, Center for Interdisciplinary Studies of Science and Culture, Kyoritsu Women's University, Hitotsubashi, Chiyoda, 非会員, 共立女子大学総合文化研究所, 千代田区一ツ橋 
い感は, 組み合わせになる相手側の服装によって異 なること，などが明らかとなった。

本報では, グループ配置の場合に，その集まり方 によって場違い感に違いが生じるのかどうかを, ラ ンダム配置の場合とあ比較しながら研究を進めた.

本報む, 前報と同様, モデル実験として人形を用い, 「場違い感」をその集まりの雾囲気と「合わない, 適 わない,ずれている」など, 服装のあたらす違和感 のこととした.

この「集合」のグループ的な効果があるのかとい う視点は, 建築系の密度研究に近い視点の研究であ る. 山崎らは, 同一教室内で机の配置の仕方によっ て, 空きスペースの密度感の感じ方が異なる研究2) や, コンコースやロビー・ラウンジの場での人の集 まり状態から, 密度感の感じ方が異なる研究34)を報 告している. これらの研究で, 1 つのスペースです その集合状態によって密度感が異なるという結果よ り，服装でも服装の集合の仕方が異なると，場違い 感す異なるのではないかと考え，このような視点か ら本研究は始まっている. ランダム配置の「集合」 の時之同様, 服装の視点からのこのような研究は, 集合における服装の差異化についての 1 つの指標に あなりうる研究と考える。

\section{2. 実験の方法}

\section{1 実験概要亡試料作成}

実験に際し，実験用空間設定に関しては前報と同 様であるため, ここでは概要のみとする.

最初に, グレーラシャ紙にて無背景な空間縱横 $1.8 \mathrm{~m}$ を設定した. そのスペースに 1 人当たり 0.09 $\mathrm{m}^{2}$ の密度になるように，36体（以下単位を「人」と する）の人形を配置した。この場合「集合」配置分 布については様々のパターンが考えられるが, 本報 では，図 1 に示す「一方の集合が中心に集まってい る場合：A 型」「一方の集合が片側に集まっている 場合：B型」「一方の集合が全体の角に集まってい る場合：C 型」「一方の集合が両側に分かれて集ま っている場合：D型」の 4 通りの「集合」配置分布 について検討した. 例えば, 図 1 の「A 型 $/ 33: 3 」$ はの印の 33 人の中央に洱印の 3 人という意味であ る.

服装に関しては，表 1 のように前報では「着物」 「赤黒ドレス」「紺スーツ」「ワンピース」「セーター ・スカート.(以下スカート)」「セーター・ジーンズ (以下ジーンズ)」の 6 種を用意し，これを「フォー
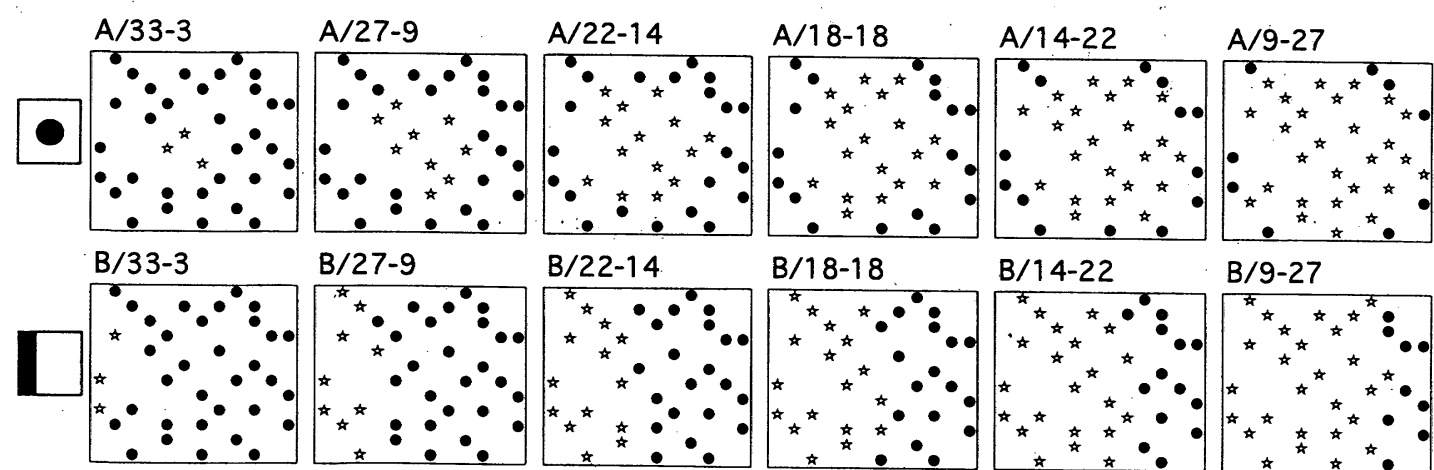

$B / 27-9$

B/22-14

B/18-18

$B / 14-22$

B/9-27
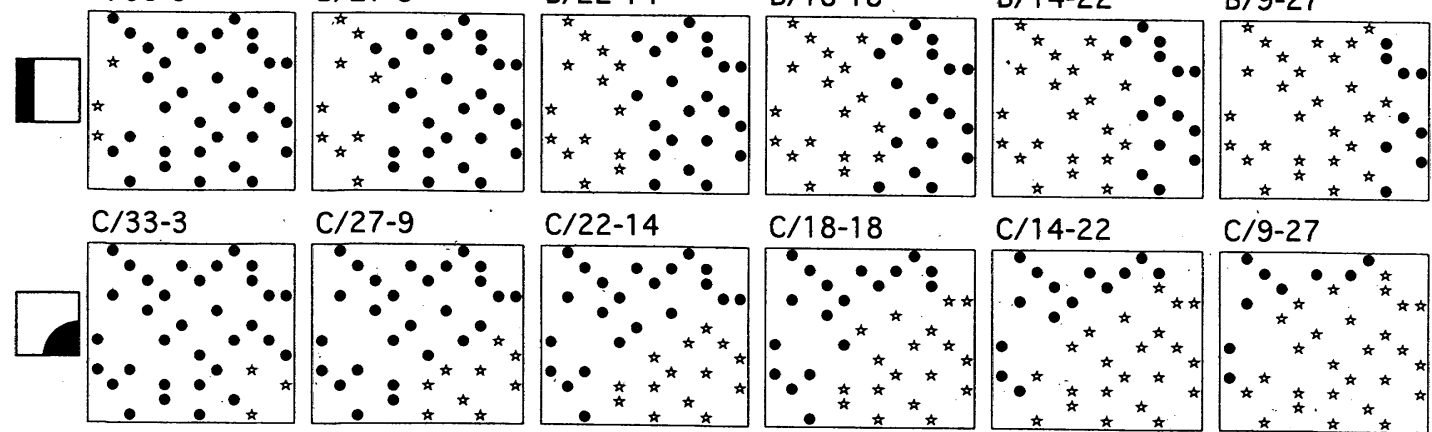

C/27-9

C/22-14

C/18-18

C/14-22

C/9-27
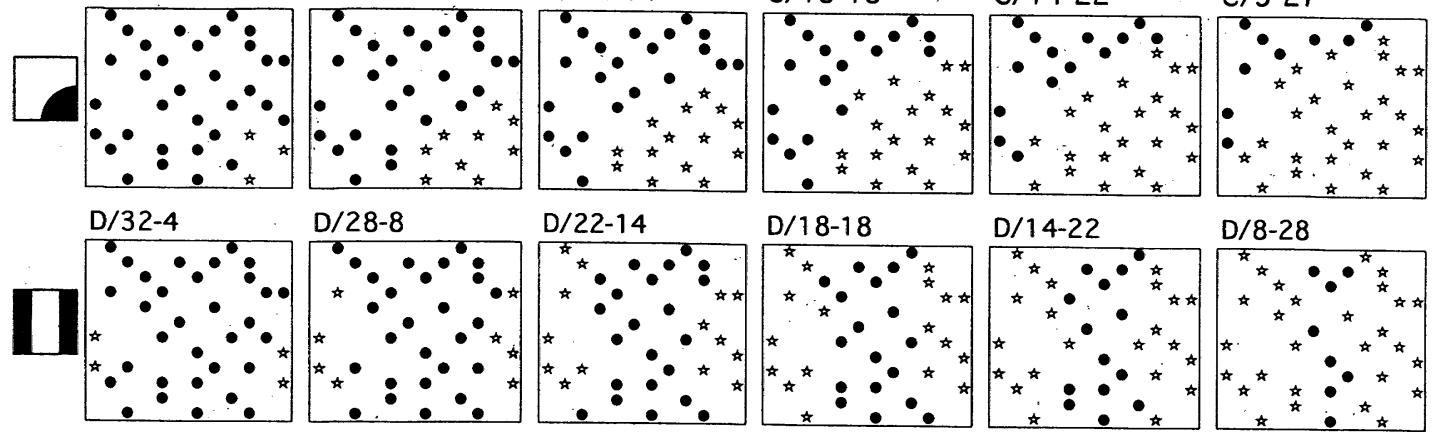

D/28-8

D/22-14
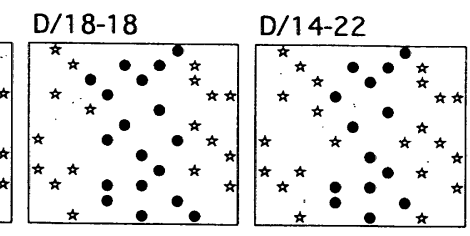

$D / 8-28$
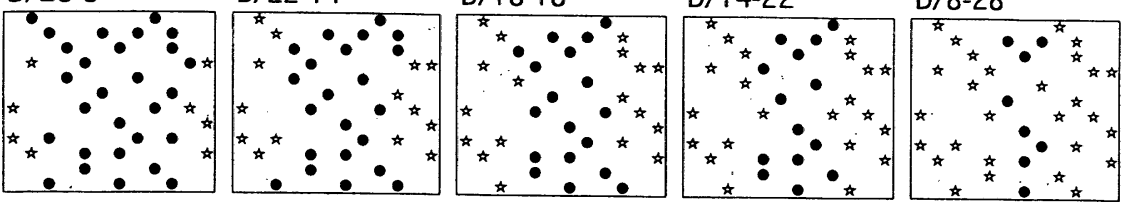

Fig. 1 Plot Plan of 36 dolls in a situation of an aggregation of groups 
Table 1 Matrix of clothes concerning range of casual from formal

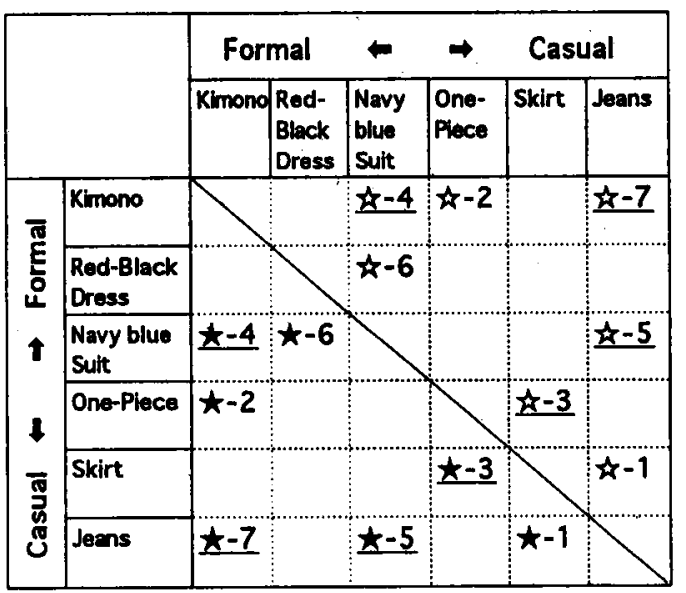

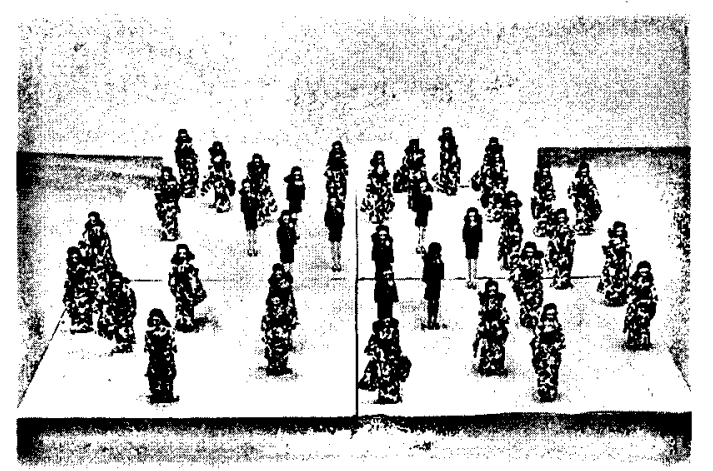

(1) A type

(Kimono 27 : Navy blue Suit 9)

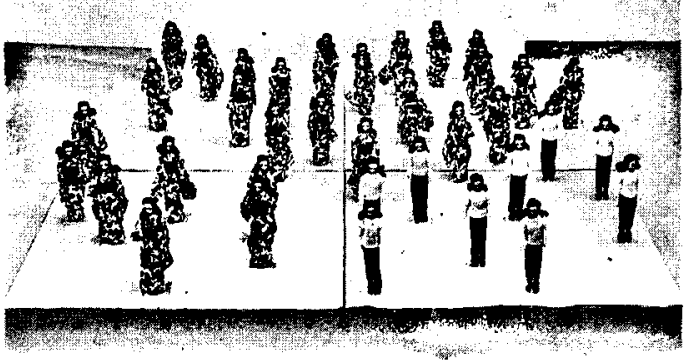

(3) C type

(Kimono 27 : Jeans 9)
マル：カシュアル」を軸に作成したマトリックスに 当てはめ 7 組還定した，今回はその中から組み合わ せになっている服装間の場逢い度が，前報のランタ 厶配置赛験において，両者とも高い〈7，ジーンス： 着物〉, 両者とも低い〈3. ワンピース:スカート〉, 一方加高くもう一方は低い〈4。緗スーツ：着物〉, 〈5. 紺スーッ: ジーンズ〉の 4 組，すなわち表 $1 の$ 下線を引いた番号の服装に絞った。 そして, 図1に 示す「集合」配置分布ことの服装比に従ってそれぞ れを人形に着装さ甘，「集合」目嘈分布別，服装比別 にスライド摄影を行った。このとき，前述したとお り前報で同頛の服装が全体の $75 \%$ を占める段陼で堨 䢖い感がほぼなくなることから，実験回数を減らす ために同類の服装が75\%を超える部分はカットし， 刺激人形数を $S=9 \sim 33$ の篹囲に絞った。 図 2 (1) (4)は， $\mathrm{A}$ 型〜D 型について服装比の一例を示したす

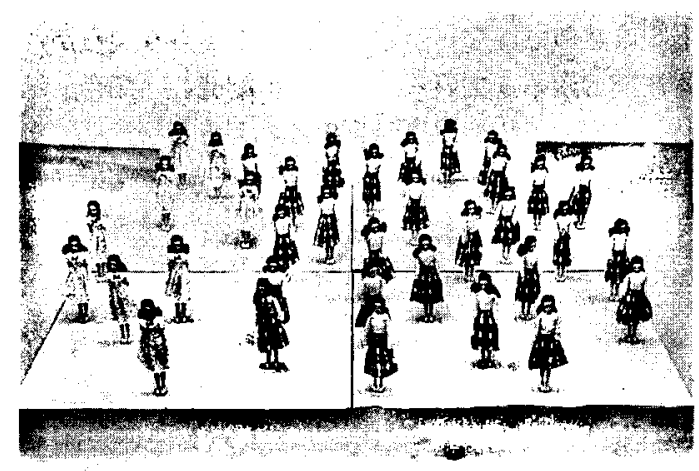

(2) B type

(Skirt 27 : One-Plece 9)

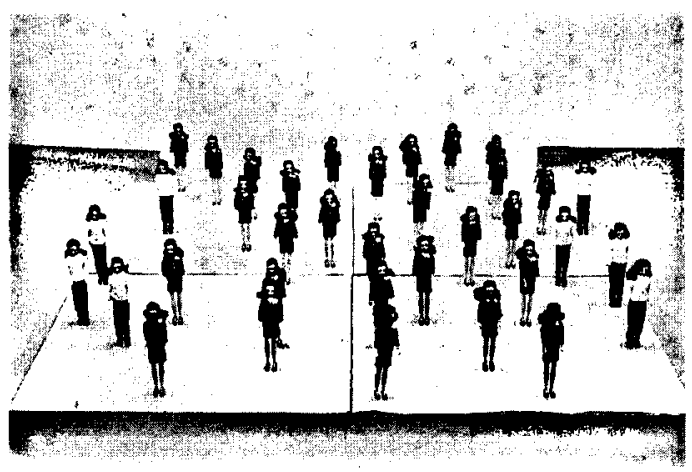

(4) D type

(Navy blue Suit 28 : Jeans 8)

Fig. 2 Photograph sample according to type of an aggregation of groups 
のである.

\section{2 実験方法}

本試料の $\mathrm{A}$ 型 D 型の計 24 パターンについて, 各々服装の組み合わせが 4 組，それを 1 組につき 「集合」内での立場を入れ替え 2 種類の服装を評価 をするため合計192パターン，それに評価練習とデ 一夕整合性を見るためのチェック用として 6 パター ン加え, 合計198パターンを途中 2 回休息を入れな がらスライドとして提示した。評価実験に際し，ラ ンダム配置の実験のときと同様, 事前に評価をして くれる人（以下，本研究では「被験者」とする）に 「場違い感」の具体例について説明し, 提示する「集 合」の中で評価してもらう方の服装について, 被験 者がその当事者として感じる「場違い感」を評価す るように指示した。なお，ここでいう具体例とは, 「和服ばかりの中で 1 人洋服だった場合や, 浴衣ば かりの中で 1 人 T シャツだった場合などに感じる 感情のこと」と説明した. スライド提示時間は, 約 3 秒である，評価尺度は，「ない」「わずかにある」 「ややある」「かなりある」「非常にある」で, 実験は 1997年11月に行い, 被験者は女子大学生119名であ る.

\section{3. 結果と考察}

\section{1 グループ配置分布別場違い感の数量的効 果}

図 3 は, 服装 4 組 8 種類のグループ配置分布 $\mathrm{A}$ 型〜 D 型と前報で用いたランダム配置分布 (以下 $\mathrm{R}$ 型とする）の人形数別の場違い度評価の平均値であ る. なお, $\mathrm{D}$ 型および $\mathrm{R}$ 型は一部 $\mathrm{A}$ 型 C 型の増加 の仕方が異なるため， $\mathrm{A}$ 型〜C 型と同数になるよう に換算しなおした．X軸には「集合」の対になって いる相手側の人形数を示し，Y 軸には「集合」内で の場違い感を〈非常にある：場違い度 5〉,〈かなり ある：場違い度 4$\rangle$,〈ややある：場違い度 3$\rangle$,〈わず かにある：場違い度 2$\rangle$,〈なし：場違い度 1$\rangle$ とし て, 実験結果を数値化した.

この $\mathrm{A}$ 型〜 D 型の各々の平均値曲線をみると, 全体36人の中で, 当事者として評価するように指示 した服装の相手側の人数が，33人， 27 人， 22 人…と 減少すると場違い感は順次急激に減少する。言い換 えると場違い感は同種の服装が全体の中で25\%（9/ 36）を占めると全体のほぼ $1 / 2$ となり, さらに全体
の75\% (27/36) を占めるとほぼなくなり, $\mathrm{R}$ 型のと きと同様に数量的効果があることが認められた.

そこで, 図 3 を両対数座標に図示すると図 4 のよ うになり， $\mathrm{A}$ 型〜 $\mathrm{D}$ 型ともに人形数が $\mathrm{S}=18 \sim 33$ の 領域では, 表 2 のように相関係数はほぼ 1.0 になる. このことから刺激と感覚の関係は両対数座標上で直 線関係として捉えることができ, Stevens の法則に 従っていると考えられる.

\section{2 グループ配置分布別場違い感の配置効果}

3.1より，これらのグループ配置分布においても

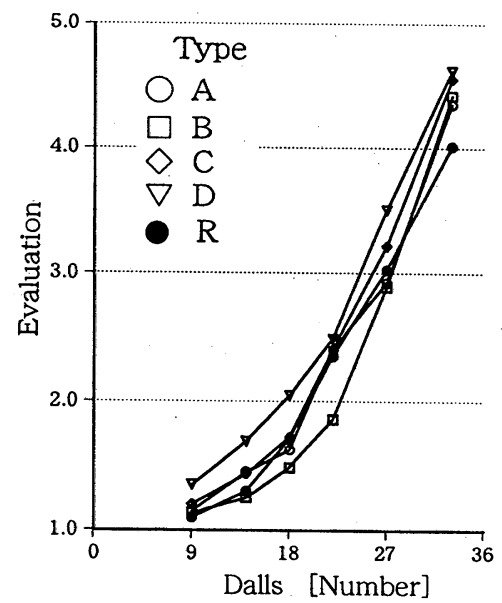

Fig. 3 Relationship between the number of the dolls and the sense of impropriety concerning $\mathrm{A}, \mathrm{B}, \mathrm{C}, \mathrm{D}$ and $\mathrm{R}$ type

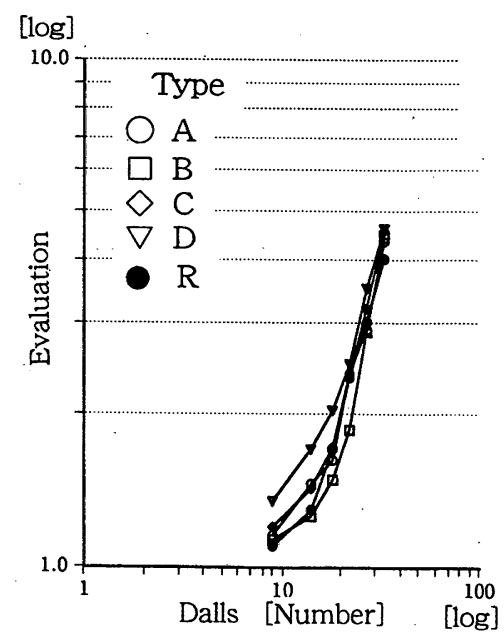

Fig. 4 Relationship between the number of the dolls and the sense of impropriety by both logarithmic coordinates 
Table 2 Correlation coefficient and coefficient of determination concerning logarithm for each type of agyregation of groups

( $\mathrm{S}=18 \sim 33)$

\begin{tabular}{|l|c|c|c|c|}
\hline & A type & B type & C type & D type \\
\hline $\begin{array}{l}\text { Correlation } \\
\text { Coefficient }\end{array}$ & 0.992 & 0.991 & 0.999 & 0.996 \\
\hline $\begin{array}{l}\text { Coefficient of } \\
\text { Determination }\end{array}$ & 0.983 & 0.981 & 0.999 & 0.992 \\
\hline
\end{tabular}

数量的効果があるごとがわかった．そこでグループ 配置分布が変化すると，その場違い感にはどのよう な違いがあるかを次に考察した。

図 3 をみると, D 型は他の型よりどの人数の時も 場違い感が高く, B 型は $S=27 \sim 14$ において場違い 感が低い，図 3 の $\mathrm{A}$ 型〜 $\mathrm{D}$ 型および $\mathrm{R}$ 型のそれぞ れの間で, 二者のグループ間の各人数における平均 值の差の検定結果を表 3 に示した。この D 型と B 型の間には, $S=27 \sim 9$ において, どの刺激数の時に あ統計的に有意であり，両者にはグループ配置の違 いによる場違い感に差があることがわかる．全体的 な傾向として $\mathrm{D}$ 型 $>\mathrm{A}$ 型・C 型・ $\mathrm{R}$ 型 $>\mathrm{B}$ 型の順
に場違い感が低くなっており，同じ人数の「集合」 でも，「集合」内での人間の集まり方によって場違い 感に変化が及ぶことを意味し，場違い感の要因には 配置効果む影響していることが認められた。

$B$ 型が他の型や $\mathrm{R}$ 型より場違い感が低いのは，自 分と同種の服装が少ない人数であっても，「集合」内 の服装が左右に二分されていることで，配置分布か ら感じる相手側からの圧迫感に欠けることや, 周囲 に同種の服装がいると感じ取り易いためではないか と考えられる. 逆に D 型では，同種の「集合」が両 端に二分されているため同じ $\mathrm{S}$ 人です，実際の $\mathrm{S}$ 人 より少ない人数に感じてしまうことや，両端にある ことでさらに「集合」の端に追いやられているよう に感じるためではないかと推測される，A 型，C型 はB 型と同じょうにまとまった「集合」ではある が，A 型は全体の中央で周りに取り囲まれている感 じや，C型は「集合」の隅にあるが手前にあるため 目立ち，B 型より場違い感が高くなったのではない がと考えられる.

また, $\mathrm{S}=33$ ，すなわち同種の服装が 3 人の時， $\mathrm{R}$ 型の場違い感が $\mathrm{A}$ 型〜 D 型より低いことについて は, $\mathrm{R}$ 型はこの 3 人が分散して配置されているた

Table 3 Result of $t$ test among A, B, C, D and R type

\begin{tabular}{|c|c|c|c|c|c|}
\hline & \multicolumn{5}{|c|}{ Number of Dolls $33\langle\langle 33: 3\rangle\rangle$} \\
\hline & A型 & & : & & \\
\hline A型 & $\mathrm{X}^{-}$ & B型 & & & \\
\hline B型 & - & 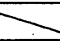 & C型 & & \\
\hline C型 & - & - & 7 & D型 & \\
\hline D型 & - & - & - & 7 & $\mathrm{R}$ 型 \\
\hline R型 & $* *$ & $\# *$ & *** & ** & \\
\hline
\end{tabular}

\begin{tabular}{|c|c|c|c|c|c|}
\hline & \multicolumn{5}{|c|}{ Number of Dolls $27\langle\langle 27: 9\rangle\rangle$} \\
\hline & A型 & & & & \\
\hline A型 & $\gamma^{-}$ & B型 & & & \\
\hline B型 & - & X & C型 & & \\
\hline C型 & - & - & 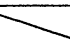 & D型 & \\
\hline D型 & * & * & - & 7 & R型 \\
\hline $\mathrm{R}$ 型 & - & - & - & ** & \\
\hline
\end{tabular}

\begin{tabular}{|c|c|c|c|c|c|}
\hline & \multicolumn{5}{|c|}{ Number of Dolls $22\langle\langle 22: 14\rangle$} \\
\hline & A型 & & & & \\
\hline A型 & 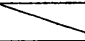 & B型 & & & \\
\hline B型 & ** & & C型 & & \\
\hline C型 & - & ** & 7 & D型 & \\
\hline D型 & - & ** & - & 7 & R型 \\
\hline R型 & - & ** & - & - & \\
\hline
\end{tabular}

* $* \mathrm{p}<0.01$

* $\mathrm{p}<0.05$

\begin{tabular}{|c|c|c|c|c|c|}
\hline & \multicolumn{4}{|c|}{ Number of Dolls $18\langle\langle 18: 18\rangle$} & \\
\hline & A型 & & 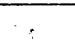 & & \\
\hline A型 & 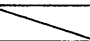 & B型 & & & \\
\hline B型 & - & 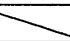 & C型 & & \\
\hline C型 & - & - & $\gamma$ & D型 & \\
\hline D型 & * & $* *$ & * & $\gamma$ & R型 \\
\hline R型 & - & - & - & - & \\
\hline
\end{tabular}

\begin{tabular}{|c|c|c|c|c|c|}
\hline & \multicolumn{4}{|c|}{ Number of Dolls $14\langle\langle 14: 22\rangle$} & \\
\hline & A型 & & & & \\
\hline A型 & 3 & B型 & - & & \\
\hline B型 & - & 7 & C型 & & . \\
\hline C型 & - & - & $\gamma$ & D型 & \\
\hline D型 & - & ** & * & 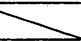 & R型 \\
\hline R型 & - & - & - & $* *$ & \\
\hline
\end{tabular}

\begin{tabular}{|c|c|c|c|c|c|}
\hline & \multicolumn{5}{|c|}{ Number of Dolls $9\langle\langle 9: 27\rangle\rangle$} \\
\hline & A型 & & & & \\
\hline A型 & $x$ & B型 & & & \\
\hline B型 & - & Y & C型 & & \\
\hline C型 & - & - & & D型 & \\
\hline D型 & ** & ** & * & $\times$ & R型 \\
\hline R型 & - & - & * & ** & \\
\hline
\end{tabular}


め, 少ない人数であっても「3箇所」に人がいると見 られるのに対し，A〜D 型は集合内で一まとまりに 存在しているため, 「1箇所」として捉えられやすい こと,さらに配置の意味的要素が $\mathrm{R}$ 型より顕著であ るためではないかと思われる。この点についは，今 後の実験でさらに検証していきたい.

\section{3 服装別にみたグループ配置分布別場違い 感の配置効果}

次に，服装別にグループ配置効果を考察した。

前述の表 1 に示した服装の組み合わせ 4 組 8 種の 服装別に, 特に前項3.2の各配置分布の平均値で差 がみられた, B 型と D 型間の平均値の差の検定結果 を表 4 に示した。これをみても B 型と D 型では, 服 装別, 人形数別の全体の約 $80 \%$ で有意な違いを示し ており，B型と D 型はいずれの服種に関係なく配置 効果が影響していることがわかる.

また，前報のランダム配置で，相手側の服装の組 み合わせ方により服装の場違い度は異なるという結 果を得ていることから， $\mathrm{R}$ 型の服装の効果を一定に するために, 同じ服装の組み合わせにおける同じ服

Table 4 Result of $t$ test between B type and D type for each clothes

\begin{tabular}{|c|l|c|c|c|c|c|c|}
\hline \multirow{2}{*}{$\begin{array}{l}\text { Kind of Clothes } \\
\text { (Combination of Clothes) }\end{array}$} & \multicolumn{6}{|c|}{ Number of Stimulus Dolls } \\
\cline { 2 - 7 } 7 & 9 & 14 & 18 & 22 & 27 & 33 \\
\hline 7 & $\begin{array}{l}\text { Kimono } \\
\text { (Jeans : Kimono) } \\
\text { (Jeans : Kimono) }\end{array}$ & $*$ & $* *$ & $* *$ & $* *$ & $* *$ & - \\
\hline 3 & $\begin{array}{l}\text { One-Piece } \\
\text { (One-Piece : Skirt) }\end{array}$ & $* *$ & $* *$ & $* *$ & $* *$ & $* *$ & - \\
\hline 3 & $\begin{array}{l}\text { Skirt } \\
\text { (One-Piece : Skirt) }\end{array}$ & - & $* *$ & $* *$ & - & $* *$ & $*$ \\
\hline 4 & $\begin{array}{l}\text { Navy blue Suit } \\
\text { (Navy blue Suit : Kimono) }\end{array}$ & $* *$ & $* *$ & $* *$ & $* *$ & $* *$ & - \\
\hline 4 & $\begin{array}{l}\text { Kimono } \\
\text { (Navy blue Suit : Kimono) }\end{array}$ & - & $*$ & - & $*$ & $* *$ & - \\
\hline 5 & $\begin{array}{l}\text { Jeans } \\
\text { (Navy blue Suit : Jeans) }\end{array}$ & $* *$ & $* *$ & $* *$ & $* *$ & $* *$ & $*$ \\
\hline 5 & $\begin{array}{l}\text { Navy blue Suit } \\
\text { (Navy blue Suit : Jeans) }\end{array}$ & $* *$ & $* *$ & $* *$ & $* *$ & - & - \\
\hline
\end{tabular}

** $\mathrm{p}<0.01$

$* \quad \mathrm{p}<0.05$
装の $\mathrm{R}$ 型場違い度評価を基準として，その $\mathrm{A}$ 型〜 $\mathrm{D}$ 型の比率と $\mathrm{R}$ 型との各々の $t$ 検定結果を図 5 に 示した. すなわち1.0のラインが $\mathrm{R}$ 型と同じ場違い 度ということになる. 図 5 の $t$ 検定結果をみると， $\mathrm{R}$ 型が $\mathrm{A}$ 型〜 $\mathrm{D}$ 型に「集合」がグループ化される と，全体の約 $40 \%$ か， $\mathrm{R}$ 型と有意な差を示し， $\mathrm{R}$ 型 のときょりす, 場違い感が高い, あるいは低いこと になる．この有意な差は，例えば，前報の $\mathrm{R}$ 型の服 装組み合わせで, 〈4. 紺スーツ：着物〉の〈紺スー ッ〉は全体的に一番場違い感が高く, 逆に〈着物〉 は低い結果であった. しかし，例えば， $\mathrm{S}=18$ みる と,〈紺スーッ〉は $\mathrm{R}$ 型より同じかそれよりあ低い 値になり，〈着物〉は逆に $\mathrm{R}$ 型より高い值となうて いる. つまり，〈4. 紺スーツ：着物〉は, あとあと は場違い度評価に開きがあったが, .グループ的に配 置することにより $\mathrm{R}$ 型と場違い感の評価が異なり, 結果的に両者の場違い感の差が縮まったものになっ たことになる。これは，「集合」の配置分布をグルー プ化することにより「隅に追いやられた」「取り曲 まれた」対立している」など，その「集合」配置分 布があたらす意味的要素が付加されたことによるの ではないかと考えられる。

\section{4. 結 言}

「集合」の集まり方によって, 服装の場違い感に違 いが生じるのかどうかを捉えるため，2 種類の服装 で構成する， 4 種類 (A 型〜D 型) のグループ配置 分布を設定し, 人形のモデル実験により検討した.

その結果，どの配置分布あ前報で行った $\mathrm{R}$ 型であ るランダム配置の時之同様に, 刺激人形数之場違い 感の間には数量的効果があり, また両者の関係は, 一定の領域で Stevens の法則に従うことが認めら れた.

また，どの服装の組み合わせであこの「集合」配 置分布は総じて $\mathrm{D}$ 型 $>\mathrm{A}$ 型・ $\mathrm{C}$ 型・ $\mathrm{R}$ 型 $>\mathrm{B}$ 型の 順に場違い感が低くなっており，同じ人数の「集合」 であ「集合」内での人間の集まり方によって場違い 感に変化が生じている，さらに，個別服装からみる と， $\mathrm{R}$ 型だけでは服装の組み合わせ間の単純な服装 効果のみの場違い感であるが, グループ化されるこ とで両者の場違い感に変化が生じることが示され, 「集合」での場違い感は, 数量的効果や相手側の服装 効果だけでなく, 配置効果によってす影響が大きい ことが明らかとなった。 

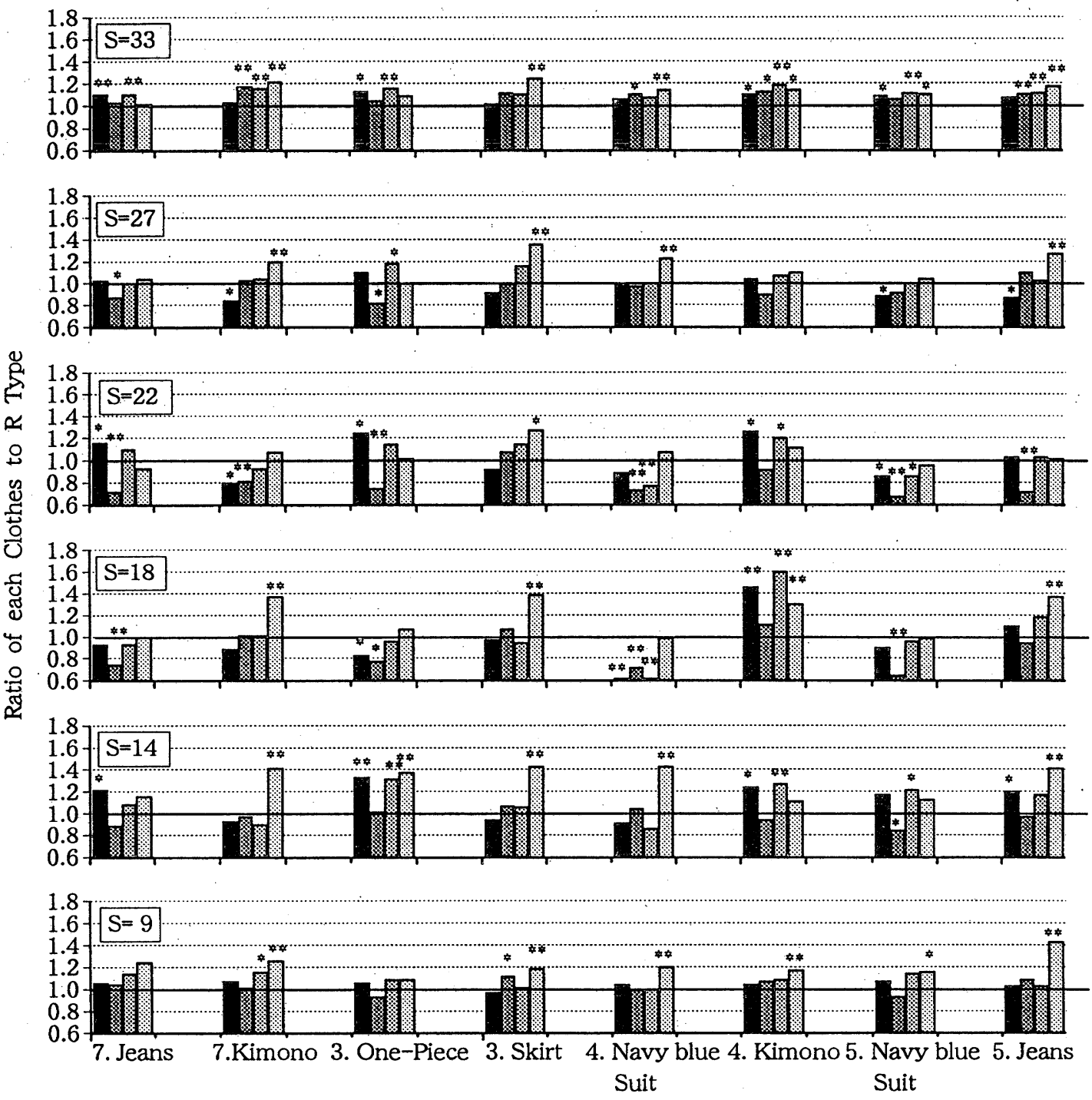

ALL Kinds of. Clothes

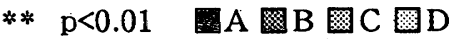 \\ * $\mathrm{p}<0.05$}

Fig. 5 Ratio of each type and each clothes to degree of impropriety evaluation of a random aggregation of people

\section{参考文献}

1) N. Uchida, S. Kobayashi and Y. Nagakura ; J. Text. Mach. Soc. Japan (Japanese Ed), 52, T80, (1999)

2) Y. Nagakura, J. Ueno and T. Yamazaki ; Educational Technology Research, 9 (4) /10 (1), 159 (1986)

3) T. Yamazaki and Y. Nagakura ; J. Architecture Plann- ing and Environmental Engineering (Transactions of AIJ), No. 386, 71 (1988)

4) T. Yamazaki and Y. Nagakura ; J. Architecture Planning and Environmental Engineering (Transactions of AIJ), No. 402, 19 (1989) 